International Research Journal of Engineering, IT \& Scientific Research
Available online at https://sloap.org/journals/index.php/irjeis/
Vol. 6 No. 6, November 2020, pages: 50-60
ISSN: 2454-2261
https://doi.org/10.21744/irjeis.v6n6.1027

\title{
Validation of Blended Learning Model of Applied Mathematics Through Schoological Networks for Learning in New Normal Era in Vocational Education
}

\author{
I Ketut Darma ${ }^{\text {a }}$ \\ I Gede Made Karma ${ }^{b}$ \\ I Made Anom Santiana ${ }^{c}$
}

Article history:

Submitted: 27 September 2020

Revised: 18 October 2020

Accepted: 09 November 2020

\section{Keywords:}

applied mathematics;

blended learning;

schoology;

validation;

vocational;

\begin{abstract}
This study aims to determine the feasibility of a model of blended learning applied mathematics using Schoology for vocational education. Research using the 4D model development method includes: Define, Design, Develop, and Disseminate, conducted at the Politeknik Negeri Bali. Data was collected using a validation sheet and student response questionnaire sheet. Data were analyzed descriptively. As a result, the design of applied mathematics blended learning using Schoology achieved: feasibility level of $84.91 \%$ (high enough), practicality $78.84 \%$ (quite practical), and compliance was $88.02 \%$ (very high). Blended learning applied mathematics is very appropriate to be used as a model of learning in vocational education. Feasible to use as a learning strategy in vocational education in the new normal era. Needs to be refined and the development process can be continued to the stage of test effectiveness, program evaluation, and dissemination.
\end{abstract}

International research journal of engineering, IT \& scientific research (C) 2020. This is an open access article under the CC BY-NC-ND license (https://creativecommons.org/licenses/by-nc-nd/4.0/).

\section{Corresponding author:}

I Ketut Darma,

Politeknik Negeri Bali, Indonesia, Indonesia.

Email address: ketutdarma@pnb.ac.id

\footnotetext{
a Politeknik Negeri Bali, Indonesia, Bukit Jimbaran, 80364 Kuta Selatan, Tuban Badung Bali, Indonesia

b Politeknik Negeri Bali, Indonesia, Bukit Jimbaran, 80364 Kuta Selatan, Tuban Badung Bali, Indonesia

${ }^{c}$ Politeknik Negeri Bali, Indonesia, Bukit Jimbaran, 80364 Kuta Selatan, Tuban Badung Bali, Indonesia
} 


\section{Introduction}

Vocational Education is an education that emphasizes the practical skills needed to jump right into the world of work. The focus of education is to equip students with a set of skills and competencies that can be used to work in certain fields or develop themselves according to their areas of expertise. Learning in the 21st century must include learning experiences for developing work capabilities and working habits in the digital era, the era of disruption, the industrial revolution 4.0 (Sudira, 2018).

A fundamental change in the 21st century, vocational higher education has a strategic role and is at the forefront of handling the age of the workforce. Vocational higher education is programmed to produce graduates who have mastery of science and technology, are independent, skilled, and trained following the demands of the industrial world or world of work. The learning outcomes are needed as capital in facing regional and global competition.

Changes in work orientation, job requirements and increasingly fierce competition in addition to demanding the need for increased competency of graduates also demand a paradigm shift regarding the teaching and learning process. This paradigm shift has an impact on the need for curriculum changes and changes in behavior and learning models. In the 21st century, vocational learning requires learning designs towards the projected development of workforce competencies with profiles that match the needs of the Industrial era 4.0 without leaving conventional needs that are still ongoing and needed in the field (Sudira, 2018).

When all components carry out changes towards the demands of the 21 st century, in early 2020 the world is faced with the emergence of an infectious disease called Coronavirus or abbreviated as COVID-19. This virus began to spread throughout the world in early 2020, to Indonesia in early March 2020 (Antara, 2020) and marked various changes in social lifestyles around the world, including in Indonesia. Because this virus is spreading rapidly and there is no medicine to handle it, WHO has designated the coronavirus as a world pandemic as the COVID-19 pandemic (BBC, 2020). To break the chain from the spread of the virus, all activities carried out by the community are carried out virtually or online (Kompas, 2020). No exception in the field of education through the Circular Letter of the Minister of Education and Culture Number 4 of 2020, the learning process at all levels of education is carried out by online learning (distance learning) (Kemendikbud, 2020a). All stakeholders must prepare all online learning tools (Kemendikbud, 2020b).

The Covid-19 pandemic forces every activity to stop, one of which is teaching and learning activities at universities. Lecture activities that initially took place face-to-face are now mostly carried out by learning online or online. Universities are required to be able to organize online learning or e-learning. Lectures are held with scenarios that can prevent physical contact between students and lecturers and students and students (Firman \& Rahayu, 2020). The lecture process is carried out using e-learning, which is considered to be the only medium for delivering material between lecturers and students in this emergency period.

According to Imania (2019), e-learning is a form of delivering conventional learning that is outlined in a digital format via the internet. The use of the internet and multimedia technology can change the way of conveying knowledge and can be an alternative to learning that is carried out in traditional classrooms (Zhang et al., 2004). The use of digital technology can allow students and lecturers to carry out the learning process even though they are in different places (Milman, 2015). E-learning can bring together students and lecturers to carry out learning interactions with the help of the internet (Kuntarto, 2017). Learning with e-learning has a level of effectiveness at least the same as face-to-face learning (Nguyen, 2015). Learning in the era of the industrial revolution 4.0 also requires e-learning (Pangondian et al., 2019).

According to Ana \& Achdiani (2015), learning in higher education should prioritize improving the quality of the process in a creative, comprehensive, and competitive manner. Learning through e-learning must remain oriented to the quality of the learning process. To achieve this, it can be done by innovating learning methods and placing students into educational subjects (student-centered learning). The innovation emphasizes the formation of active and accommodating self-understanding based on prior knowledge and meaningful learning experiences, involving students actively sharing knowledge between lecturers and students, students with friends in groups, and during class-level discussions virtually or offline.

The use of e-learning is used as a learning solution during the 2019 Covid pandemic. However, behind its excellence, there are some obstacles. The biggest obstacle to e-learning is direct interactivity between students and their instructors, learning is a two-way process. Students need feedback from the teacher and vice versa the teacher also needs feedback from students (Noer, 2013). On the other hand, Indonesia's diverse regions mean that not all areas are covered by internet services and the distribution of the internet network is slow at times (Khasanah et al.,

Darma, I. K., Karma, I. G. M. ., \& Santiana, I. M. A. . (2020). Validation of blended learning model of applied mathematics through schoological networks for learning in new normal era in vocational education. International Research Journal of Engineering, IT \& Scientific Research, 6(6), 50-60. https://doi.org/10.21744/irjeis.v6n6.1027 
2020). The ability of parents to provide online education facilities (Obiakor \& Adeniran, 2020). The use of the internet network costs money (Jones \& Sharma, 2020; Purwanto et al., 2020).

There are obstacles or inconsistencies with learning that should be, many think that the responsibility of teachers in implementing e-learning is lighter than traditional learning (Semradova \& Hubackova, 2016). Lack of equipment, personnel, resources, and the limitations of educational technology, as well as the skills and quality of teachers, are not sufficient (Dursun et al., 2013; Jaya, 2017). Network connections and technical errors such as server downs and errors hinder successful learning (Nurmukhametov et al., 2015). Hypermedia technology does not have added value if it is used only to replace tasks that use handwritten paper (Yengin et al., 2011). The teacher's creativity in providing material through the media is also needed as a factor that influences students' interest in learning in elearning (Simbolon, 2014). Accepting the concepts and principles of material will be difficult in e-learning without face-to-face although educators can take advantage of learning media in the learning process such as power points, hyperlinks, video tutorials, compact disks (CDs), and interactive multimedia based on CAI (Abdi et al., 2017). The learning process is not just a transfer of knowledge, but also a transfer of values that is reflected in the direct interaction between lecturers and students. The process of interaction between lecturers and students, and between students and students is very necessary for building character and human aspects. Learning through e-learning can bring distant things closer, but often distances them close. Thus technology must be placed in its portion as a medium to assist the educational process. The total use of technology only applies during emergencies such as the COVID-19 pandemic. To complement each other between e-learning and conventional learning, a Blended Learning model can be used. Blended learning as a solution to overcome the weaknesses of e-learning pursuit (Noer, 2013; Husamah, 2014). Blended learning is considered capable of bridging the demands of information system progress that is growing very rapidly and demands to maintain noble values or national character (Humasah, 2013).

Graham (2006), states that Blended learning is an approach that integrates face-to-face teaching and computerassisted instructional activities (computer-mediated instruction) in a pedagogic environment. Blended learning is a formal education program where students get a part of learning through online learning that controls time, place, choice of material, speed of learning in the hands of students, and part of learning (Watson \& Murin, 2014). Semler (2005), asserts that: Blended learning combines the best aspects of online learning, structured face-to-face activities, and real-world practice. Online learning systems, in-class exercises, and on-the-job experiences will provide them with valuable experiences. Blended learning uses an approach that empowers various other sources of information. Blended learning is a method that creates a learning environment suitable for students in higher education (Castro, 2019). The Blended Learning model can improve students' understanding (Bibi \& Jati, 2015). The prerequisite for the learning device has been well prepared by the teacher (Abdullah, 2018). In blended learning, students can learn more effectively in an integrated learning environment (Eryilmaz, 2015). New Normal "is a term for a new life order or guidance for a new life order that can be done during the COVID-19 pandemic. All sectors are currently preparing for the new normal or new normal, including the education sector. The Ministry of Education and Culture has given the green light that schools In areas where the COVID-19 case is in the green category, they can return to face-toface learning. But still, strictly enforce health protocols. Blended learning is considered to be the right step to respond to current conditions and can even become an educational innovation during the COVID-19 pandemic (Soekendro, 2020). Learning in tertiary institutions requires students to be active in developing material obtained from lecturers at face-to-face and outside lectures. The development of the blended learning model will encourage the acceleration of student information and knowledge so that it will enhance effective learning. Effective learning can form an active and productive learning atmosphere for students (Fry et al., 2008). The development of webbased blended learning demands that learning is not only focused on class hours, but learning will continue outside the classroom with online media in web-based media.

Implementing blended learning requires an application, namely the learning management system (LMS). Learning Management System (LMS) is an application or software used to manage online learning, covering several aspects, namely material, placement, management, and assessment (Mahnegar, 2012). Several types of LMS can be used in the learning process, namely: Schoology, Learnboos, Edmodo, Moodle, and others. Schoology is an LMS in the form of a social web that offers to learn the same as in the classroom for free (free) and is easy to use as social media Facebook. Schoology is an e-learning platform that is interesting and fun in learning. The advantages of Schoology compared to other LMS include using terms that we usually use on the Facebook, Moodle, and Edmodo social networks such as recent activities, messages, courses, resources, groups, assignments, and attendance. Another advantage is that attendance figures are available by choosing to attend, permission, being late, or not entering. Every student activity will also be monitored through analytic facilities on course courses, assessments, discussions, and other activities that are provided for students. Sicat's (2015), research results show that Schoology is effectively used 
to apply blended learning. Joshua et al., (2015), proved that there was an increase in the high category for the motivational aspects of students who were taught using Schoology.

This study aims to obtain a blended learning design applied mathematics using the Schoology application implemented in stages over 3 stages of time. The first stage has got a draft of the blended learning design. Currently, the development stages of product validation and testing are being carried out. The goal is to determine the feasibility of a blended learning design in applied mathematics during the COVID-19 pandemic.

\section{Materials and Methods}

This research is development research using a 4-D model including the stages: 1) Define, 2) Design, 3) Develop, and 4) Disseminate. Implementation in the field of engineering at the Bali State Polytechnic, for 3 years. Samples were taken using purposive sampling from 196 people distributed in 3 departments and 6 study programs.

The define and design stage is the development needs analysis stage. At this stage, a field survey and literature review are carried out. The field survey was carried out on students and lecturers in the field of Politeknik Negeri Bali engineering, which is related to the availability of internet facilities, student characteristics in learning, and student perceptions of currently applied mathematics learning (Zayed, 2011; El-Kalla, 2008). Furthermore, draft I of a mathematical blended learning model and its tools are constructed. The tools compiled include a blended learning design, a Semester Recovery Plan (SRP), teaching materials, and online learning classes using the Schoology application. Blended learning design, involves a mixed learning design between face to face and online using a problem-based learning approach. The design specification is online learning - face to face - online learning. While classes and online learning content are class designs and content that can be used by lecturers to facilitate students learning online, both independently and collaboratively. In online classes, several parts can be used by lecturers to carry out learning, provide material, assignments, and evaluate students.

The development stage, to get a validated draft II of the blended learning design. This stage is carried out through: 1) expert appraisal, 2) revision, 3) trial. Currently only done until the validation and testing phase. The assessment was carried out by filling out a validation questionnaire on the design aspects of Draft I. The dissemination stage is the use of learning models that have been developed on a broader scale such as other classes and other teachers. The goal is to test the effectiveness and evaluation of learning models in learning activities.

Data were collected using methods: survey, observation, and interviews. The instrument is compiled by the researcher based on the variables which are translated into research indicators. The answer for each instrument item using a Likert scale has a gradient from very positive to very negative. Furthermore, the data were analyzed using descriptive statistics. The validity of the model is determined by the suitability of the validation results with the specified validity criteria. According to Akbar (2013), one of the criteria that can be used is as in Table 1 below.

Table 1

The criteria for the validity of the learning model

\begin{tabular}{lll}
\hline No & Validity Criteria & Level of validity \\
\hline 1 & $85.01 \%-100 \%$ & Very valid, or can be used without revision \\
2 & $70.01 \%-85.00 \%$ & Quite valid, or can be used but needs minor revisions \\
3 & $50.01 \%-70.00 \%$ & Less valid, or suggested not to be used because it needs major revisions \\
4 & $01.0 \%-50.00 \%$ & Not valid, or may not be used \\
\hline
\end{tabular}

\section{Results and Discussions}

This research is development research using the 4-D model, carried out multi-years for 3 years. The first stage this year (2019) has obtained the first draft product of the Blended learning applied mathematics model, using the help of the Schoology application LMS. The components, 1) online learning, 2) face-to-face learning, 3) independent learning, 4) applications, 5) tutorials, 6) collaboration, and 7) evaluation. Its development is based on learning theories: Behaviorism, Humanism, Cognitivism, and Constructivism (Richey et al., 2011; Asmendri \& Sari, 2018). The design includes, 1) learning outcomes, 2) material organization map, 3) reference list, 4) teaching materials, 5) synchronous and asynchronous learning activities, 6) asynchronous learning design, 7) synchronous learning design,

Darma, I. K., Karma, I. G. M. ., \& Santiana, I. M. A. . (2020). Validation of blended learning model of applied mathematics through schoological networks for learning in new normal era in vocational education. International Research Journal of Engineering, IT \& Scientific Research, 6(6), 50-60. https://doi.org/10.21744/irjeis.v6n6.1027 
and 8) synchronous learning flow. The composition of face-to-face learning and online learning 30/70 (Cheung \& Hew, 2011; Dwiyogo, 2018; Chaeruman, 2013). The combination of synchronous and asynchronous learning arrangements refers to the concept of 4 quadrants of learning arrangements (Dwiyogo, 2018; Smaldino et al., 2012; Chaeruman, 2013). Learning uses a problem-based learning approach. The syntax of the Blended Learning Applied Mathematics model is designed to take into account the views, behavioristic, humanism, cognitive, and constructivist. The social system implicit in the blended learning model is the synchronization of interactions between lecturers and students. Interaction occurs when the lecturer advises students to access the learning website, so the students do or access the learning web. The principle of reaction is a guideline for lecturers to appreciate and respond to stimuli in the form of student behavior in the learning process. The principle of reaction is a guideline for lecturers to appreciate and respond to stimuli in the form of student behavior in the learning process, namely: 1) creating a conducive atmosphere for learning, 2) providing and managing learning resources; 3) conveying information about e-learning; 4) guiding students to learn and guide solving problems; and 5) appreciating and directing all student activities during the learning process. Lecturers as facilitators, motivators, moderators, and consultants (Joyce et al., 2004). Support system: computer units, networks, students' ability to access learning webs, semester study plans (SSP), learning media, and evaluation sheets. The learning web was developed using the Learning Management System (LMS) Schoology model. Other supporting systems needed, namely: 1) teaching materials; 2) eSAS and 3) assessment instruments, and 4) e-learning media (Suparno, 2000). Expected instructional impact: mastery of applied mathematics textbook material; a positive attitude towards textbooks, the learning outcomes achieved, and the ability to construct knowledge, seen from test answers and during face-to-face discussions and online learning through online discussion activities. While the accompanying impact, namely: independence in learning, learning motivation and increased learning activeness.

Blended learning applied mathematics is designed for one semester with a total of 2 credits, using the LMS Schoology model application, which can be visited via the page of ww.schoology.com. The main menu display: Upgrade, Courses, Groups, and Resources. Courses as a facility to create class subjects. Group facilities to create groups. While Resources are a part to place learning materials or resources. In the Courses menu, there is material courses sub-menu as a place to make various needs in the learning process and assessment of learning outcomes. Course material consisting of assignments, tests/quizzes, files, and links to external tools, discussions, pages, and media album (Nugraha, 2020; Ariani \& Helsa, 2019; Rohman, 2017). The display draft of applied mathematics online learning uses the LMS Schoology model as shown in Figure 1.

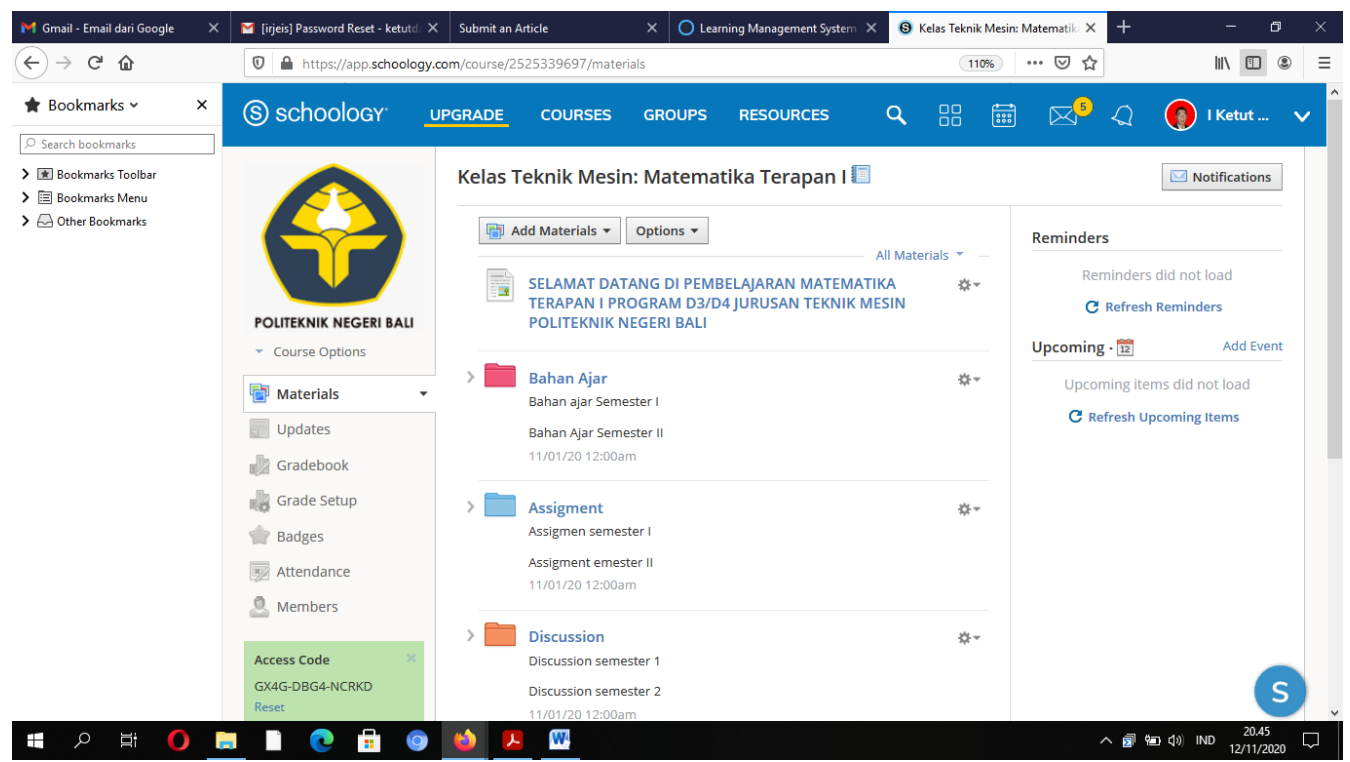

Figure 1. Draft online learning applied mathematics using schoology

Currently the 2nd year stage is being carried out, namely the development stage including: expert validation and testing to get draft II. The validation of draft I begin with the development stage which designing a blended learning model in the form of a draft guide containing the background, concepts, and characteristics of the learning model which consisting of syntax, social systems, reaction principles, support systems, instructional impacts, and 
accompaniment impacts (Rusman \& Cepi, 2012; Akbar, 2013). Expert validation: 1) validation of learning experts, material content, media, and design; and 2) user validation (Akbar, 2013). The summary of the validation results from experts, users, and audiences are presented in table 2 below.

Table 2

Recapitulation of validation results from experts, users, and audiences

\begin{tabular}{lllll}
\hline No & Experts/Users & Average & Percentage $(\%)$ & Category \\
\hline 1 & Learning & 3.32 & 82.95 & valid \\
2 & Content of learning material & 3.6 & 90 & Very valid \\
3 & Media & 3.4 & 84.3 & valid \\
4 & Design & 3.2 & 80.3 & valid \\
5 & Users & 3.5 & 87 & valid \\
& Average & $\mathbf{3 . 4}$ & 84.91 & valid \\
\hline
\end{tabular}

The score of the assessment results from the five validators decided that the draft Blended learning model could be quite feasible (84.91\%) and could be used in applied mathematics learning with several minor revisions. The revision, especially in the statement items that explain the background of the model and the learning steps which was considered less valid because it obtained an average of 2.67. In addition to the background, there is also the addition of learning theories that underlie the learning model so that the model stage has a theoretical basis to be applied. The learning steps are adjusted according to the PBL syntax referred to. The support system was also revised by adding an explanation of the support system that must be present in implementing the model. The purpose of developing the learning model is also more specified with the instructional impact. Input from the validator is used as the basis for making revisions to achieve the feasibility of the learning model.

The results of the revision of Draft I are referred to as draft II, followed by the small group test and large group test stages. Small group and large group tests are carried out in the field of engineering Bali State Polytechnic. Small group and large group tests were conducted in the field of PNB engineering from January to February 2020. The small group test involved 9 students with low, medium, and high qualifications from each study program. While the large group test involved 27 students who were distributed in each study program. The recapitulation of student responses in the two stages of the test, the percentage of average scores obtained were $75.57 \%$ and $78.84 \%$, categorized as quite practical. This means that the web schoology of applied mathematics learning that was developed is quite feasible and practically used by the users. Furthermore, after making minor revisions on the parts that received a low response, a limited trial was carried out. The goal is to find out the feasibility of the learning model. The limited trial involved 196 students in each engineering study program.

During a limited trial, it was assisted by a student activity observation sheet instrument. Observations were carried out during the trial process when face to face takes place. The goal is to determine the feasibility of the model through student activities that appeared when the web schoology of mathematics learning is implemented. The recapitulation of the student results analysis is presented in table 3.

Tabel 3

Recapitulation of student activity analyisis results

\begin{tabular}{lll}
\hline No & Aspect & $\begin{array}{l}\text { Percentage } \\
(\%)\end{array}$ \\
\hline 1 & Asking & 89.40 \\
2 & Access animation / video media & 89.95 \\
3 & Make a summary & 45.35 \\
4 & Discussion with groups & 98.89 \\
5 & Work in groups & 98.48 \\
6 & Express opinions & 85.42 \\
7 & Listening to explanations / information & 97.64 \\
8 & Be confident in learning activities & 99.00 \\
& Average & 88.02 \\
\hline
\end{tabular}

Darma, I. K., Karma, I. G. M. ., \& Santiana, I. M. A. . (2020). Validation of blended learning model of applied mathematics through schoological networks for learning in new normal era in vocational education. International Research Journal of Engineering, IT \& Scientific Research, 6(6), 50-60. https://doi.org/10.21744/irjeis.v6n6.1027 
Based on table 3, the percentage of limited trial implementation is quite high, namely $88.02 \%$. This is in line with the student activities that most appear when the students asking questions, discussing in groups and they are very confident during the limited trial of web Schoology in applied mathematics learning. The lowest activity is that students do not make summaries during the trial phase. This condition description is in line with the role of the internet as a learning resource, learning using the web allowed students to be able to access material from anywhere without having to make a summary in a notebook (Rusman, 2011).

During a limited trial, it was found deficiencies and errors in using the web schoology of mathematics learning. These errors and shortcomings include user name errors, organizing the material, there are several layouts in web design that do not match the actual appearance of web design for some laptops, student skills in writing mathematical symbols with the equation, and file storage. Also, there are some inputs from students, such as the attractiveness of colors and types of questions available. Based on the shortcomings and inputs obtained, the applied mathematics Schoology web was revised again therefore it can produce a very valid and practical web.

The results of validation and testing show that the model developed is quite feasible, practical, and useful to use. The blended learning model using Schoology in this applied mathematics course has fulfilled the learning aspects, namely: feasibility, practicality, and utility (Trianto, 2015; Rusman \& Cepi, 2012; Akbar, 2013). The model design still needs to be revised. Before proceeding to the process of testing the effectiveness and evaluation at the next stage, the design was refined following the conditions of the Covid 19 pandemic, because development had started before the pandemic. Face-to-face learning before the pandemic was carried out with live synchronicity, while during a pandemic it was carried out via a virtual conference using the zoom meeting or wibex application (Chaeruman, et al., 2020).

The blended learning model developed by learners uses a problem-based learning approach, combining face to face meetings with online learning assisted by Schoology applications. The learning process will be able to provide ample opportunities for students to be active and constructive. The use of this model will be able to make students creative and critical in using technology in learning. Their insights become broader and the reference for solving problems becomes wider. This model can balance weaknesses by combining traditional learning methods and online learning (Munir, 2009). Face-to-face learning allows for interactive learning while online learning can provide online material without time and space limits so that maximum learning can be achieved (Sutopo, 2012). Giving problems during learning can encourage students to explore curiosity and detail on all problems and concepts in the given problem (Uden \& Beaumon, 2006). This can increase the level of learning interaction and learning activities between students and lecturers, in the end, it can increase knowledge collaboration between students and teachers, and improve problem-solving skills. So that the effective application of the blended learning model of applied mathematics will be able to encourage improving the ability to solve math problems for students. The prerequisite for the learning device has been well prepared by the teacher (Abdullah, 2018). These results strengthen support for research results from Bibi \& Jati (2015); Manggabarani et al., (2016); Kholifah \& Buditjahjanto ( 2016); Sudiarta \& Sadra (2016); and Al Ayyubi et al., (2018).

21st-century vocational learning is learning the development of work competency capabilities of students who are ready to solve various problems in society and the world of work. The learning must include learning experiences of developing work capabilities and working habits in the digital era, the era of disruption, welcoming the industrial revolution 4.0. The learning concept is based on the learning theory of behaviorism, cognitivism, constructivism, life-based learning, transformative, and social partnership learning (Sudira, 2018). Education is required to always be able to adapt to changing conditions, technology, and the demands of the world of work. The curriculum integrates new competencies and literacy that are relevant to the world of work in the industrial revolution era 4.0. Learning models and modes need to be flexible, apply face-to-face learning and information technology-based learning to build students into independent learners. The education process before and during a pandemic must produce qualified graduates according to industry needs.

The success in achieving learning objectives in vocational education does not only depend on the quality of the curriculum that has been compiled (Finch \& Crunkilton, 1999). Success in achieving learning outcomes is also determined by the design of the learning process that is appropriate to the characteristics of vocational education. Blended learning is developed based on the learning theory of Humanism, Behaviorism, Cognitivism, and Constructivism (Rusman, 2011; Dwiyogo, 2018; Ginaya et al., 2018). Blended learning is following the realm of vocational education. Along with the use of e-learning during a pandemic period, blended learning is appropriate as a learning strategy in vocational education in the new normal. Learning that is supported by online learning methods can have a positive effect on increasing student motivation and therefore can have a positive effect on academic success (Yagci, 2016; Garrison \& Kanuka, 2004; Stockwell et al., 2015). Blended learning is very suitable for 
encouraging collaborative and constructive learning which places a strong emphasis on the current learning style and environment (Wong et al., 2016). So that the blended learning model of applied mathematics using Schoology which is being developed greatly contributes to efforts to improve the quality of learning in vocational education.

The blended learning model is not only effective, efficient, and attractive for students, but can build a learning community between students and lecturers. Blended learning can be used as an alternative type of learning that is effective, efficient, and able to support learning community facilities for students (Purwaningsih \& Pujianto, 2009). The blended learning model is appropriate for use in the current learning process, especially in the era of industrial revolution 4.0. Blended learning is very appropriate. be an educational innovation that is used to respond to the conditions of the Corona-19 pandemic, is the right solution in efforts to improve learning and become ideal learning in the New Normal Era (Fatmawati, 2020; Lewis, 2020).

The blended learning model that is being developed is suitable for use in the new normal era. The model used is the enriched virtual model with the concept of $30 \%$ face-to-face $70 \%$ e-learning. When traditional learning is implemented, health protocols must be strictly applied to prevent the spread of COVID-19. Optimization of the learning process in the era of the Covid 19 pandemic and the current new normal will be effective and efficient by using the blended learning method. The learning process combines two strategies in blended learning, namely synchronous and asynchronous strategies. According to Chaeruman et al. (2020), a live synchronous learning room cannot be applied. The learning process that takes place can use the other three learning spaces as virtual synchronous, independent asynchronous, and collaborative synchronous. These three learning spaces have become a habit for teachers, students, and parents. The three of them have become spirits in the learning process carried out during the pandemic.

\section{Conclusion}

The Schoology-based blended learning model of applied mathematics in vocational education achieved: feasibility of $84.91 \%$ (high enough), practicality $78.84 \%$ (quite practical), and compliance was $88.02 \%$ (very high). Feasible to use as a learning strategy in vocational education in the new normal era. Needs to be refined into draft III, and the development process can be continued to the stage of test effectiveness, program evaluation, and dissemination.

\section{Conflict of interest statement}

The authors declared that they have no competing interests.

\section{Statement of authorship}

The authors have a responsibility for the conception and design of the study. The authors have approved the final article.

\section{Acknowledgments}

The author would like to thank Directorate Research and Social Service, Ministry of Research, Technology, and Higher Education for their financial support that this research was successfully undertaken. 


\section{References}

Abdi, M., Bachtiar, G., \& Daryati, D. (2017). Penggunaan Multimedia Interaktif Berbasis Computer Assisted Instruction (CAI) pada Topik Pembahasan Baja Sebagai Bahan Bangunan. Jurnal Pensil: Pendidikan Teknik Sipil, 6(2), 83-91.

Abdullah, W. (2018). Model blended learning dalam meningkatkan efektifitas pembelajaran. Fikrotuna, 7(1), 855866.

Akbar, S. (2013). Instrumen Perangkat Pembelajaran, Bandung. PT Remaja Rosda Karya.

Al Ayyubi, I. I., Nudin, E., \& Bernard, M. (2018). Pengaruh Pembelajaran Berbasis Masalah terhadap Kemampuan Pemecahan Masalah Matematis Siswa SMA. JPMI (Jurnal Pembelajaran Matematika Inovatif), 1(3), $355-360$.

Ana, A., \& Achdiani, Y. (2015). Penerapan Self Regulated Learning Berbasis Internet untuk Meningkatkan Kemandirian Belajar Mahasiswa. Innovation of Vocational Technology Education, 11(1).

Ariani, Y., \& Helsa, Y. (2019). Desain Kelas Digital Menggunakan Edmodo Dan Schoology. Deepublish.

Asmendri, A., \& Sari, M. (2018). Analisis Teori-Teori Belajar pada Pengembangan Model Blended Learning dengan facebook (MBL-FB). NATURAL SCIENCE: Jurnal Penelitian Bidang IPA dan Pendidikan IPA, 4(2), 604-615.

Bibi, S., \& Jati, H. (2015). Efektivitas model blended learning terhadap motivasi dan tingkat pemahaman mahasiswa mata kuliah algoritma dan pemrograman. Jurnal Pendidikan Vokasi, 5(1), 74-87.

Castro, R. (2019). Blended learning in higher education: Trends and capabilities. Education and Information Technologies, 24(4), 2523-2546.

Chaeruman, U. A. (2013). Merancang Blended Learning yang membelajarkan. In Seminar Nasional" Meningkatkan Kualitas Pembelajaran Melalui Sumber-Sumber dan Teknologi yang Tepat". Surakarta: UNS.

Chaeruman, U., Wibawa, B., \& Syahrial, Z. (2020). Development of an Instructional System Design Model as a Guideline for Lecturers in Creating a Course Using Blended Learning Approach.

Cheung, W. S., \& Hew, K. F. (2011). Design and evaluation of two blended learning approaches: Lessons learned. Australasian Journal of Educational Technology, 27(8).

Dursun, T., Oskaybaş, K., \& Gökmen, C. (2013). The quality of service of the distance education. Procedia-Social and Behavioral Sciences, 103, 1133-1151. https://doi.org/10.1016/j.sbspro.2013.10.441

Dwiyogo, W. D. (2018). Pembelajaran berbasis blended learning. Diakses dari.

El-Kalla, I. L. (2008). Convergence of the Adomian method applied to a class of nonlinear integral equations. Applied mathematics letters, 21(4), 372-376. https://doi.org/10.1016/j.aml.2007.05.008

Eryilmaz, M. (2015). The effectiveness of blended learning environments. Contemporary Issues in Education Research (CIER), 8(4), 251-256.

Fatmawati, K. (2020). Blended Learning, Pembelajaran Ideal di Era New Normal.

Finch, C. R., \& Crunkilton, J. R. (1999). Curriculum development in vocational and technical education. planning, content, and implementation. Allyn and Bacon, 160 Gould Street, Needham Heights, MA 02494.

Firman, F., \& Rahayu, S. (2020). Pembelajaran Online di Tengah Pandemi Covid-19. Indonesian Journal of Educational Science (IJES), 2(2), 81-89.

Fry, H., Ketteridge, S., \& Marshall, S. (2008). A handbook for teaching and learning in higher education: Enhancing academic practice. Routledge.

Garrison, D. R., \& Kanuka, H. (2004). Blended learning: Uncovering its transformative potential in higher education. The internet and higher education, 7(2), 95-105. https://doi.org/10.1016/j.iheduc.2004.02.001

Ginaya, G., Rejeki, I. N. M., \& Astuti, N. N. S. (2018). The effects of blended learning to students' speaking ability. International journal of linguistics, literature and culture, 4(3), 1-14.

Graham, C. R. (2006). Blended learning systems. The handbook of blended learning: Global perspectives, local designs, 3-21.

Husamah, H. (2013). Pembelajaran Luar Kelas (Outdoor Learning). Research Report.

Husamah, H. (2014). Pembelajaran bauran (Blended learning). Research Report.

Imania, K.N. (2019). Rancangan Pengembangan Instrumen Penilaian Pembelajaran Berbasis Daring. Jurnal PETIK. $5(1), 31-47$.

Jaya, H. N. (2017). Keterampilan Dasar Guru untuk Menciptakan Suasana Belajar yang Menyenagkan. Didakt. J. Pendidik. dan Ilmu Pengetah, 17(1), 23-35.

Jones, K., \& Sharma, R. (2020). On Reimagining a Future for Online Learning in the Post-COVID Era. First posted on medium. com. 
Joshua, J. N., Swastika, I. P. A., \& Estiyanti, N. M. (2016). The effectiveness of e-learning implementation using social learning network schoology on motivation \& learning achievement. Jurnal Nasional Pendidikan Teknik Informatika: JANAPATI, 5(1), 28-33.

Joyce, B., Weil, M., \& Calhoun, E. (2004). Models of Teaching (7th ed), Boston: Pearson Education, Inc, 2004.

Kemendikbud. (2020a). Surat Edaran Kemendikbud Nomor 4 Tahun 2020.

Kemendikbud. (2020b). Surat Edaran Kemendikbud Nomor 15 Tahun 2020.

Khasanah, D. R. A. U., Pramudibyanto, H., \& Widuroyekti, B. (2020). Pendidikan Dalam Masa Pandemi Covid19. Jurnal Sinestesia, 10(1), 41-48.

Kuntarto, E. (2017). Keefektifan Model Pembelajaran Daring dalam Perkuliahan Bahasa Indonesia di Perguruan Tinggi. Indonesian Language Education and Literature, 3(1), 99-110.

Lewis, D. E. (2002). A departure from training by the book, more companies seeing benefits of e-Learning. The Boston Globe, Globe Staff, 5(26), 02.

Mahnegar, F. (2012). Learning management system. International Journal of Business and Social Science, 3(12).

Manggabarani, A. F., Sugiarti, S., \& Masri, M. (2016). Pengaruh Model Pembelajaran Blended Learning Terhadap Motivasi dan Hasil Belajar Siswa Kelas X SMA Negeri 1 Pitumpanua Kab. Wajo (Studi Pada Materi Pokok Sistem Periodik Unsur). Chemica: Jurnal Ilmiah Kimia dan Pendidikan Kimia, 17(2), 83-93.

Milman, N. B. (2015). Distance education.

Munir, D., \& IT, M. (2009). Pembelajaran jarak jauh berbasis teknologi informasi dan komunikasi. Bandung: Alfabeta.

Nguyen, T. (2015). The effectiveness of online learning: Beyond no significant difference and future horizons. MERLOT Journal of Online Learning and Teaching, 11(2), 309-319.

Noer, M. (2013). Blended Learning Mengubah Cara Kita Belajar di Masa Depan.

Nugraha, T., S. (2020). Schoology untuk Pembelajaran Jarak Jauh. Yogyakarta: CV. Tsaqiva Publishing.

Nur Kholifah, S. I. T. I., \& Asto Buditjahjanto, I. (2016). Pengaruh model pembelajaran blended learning terhadap hasil belajar dan motivasi belajar siswa kelas XI TEI pada mata pelajaran komunikasi data dan interface di SMK Negeri 1 Jetis Mojokerto. Jurnal Pendidikan Teknik Elektro, 5(3).

Nurmukhametov, N., Temirova, A., \& Bekzhanova, T. (2015). The problems of development of distance education in Kazakhstan. Procedia-social and Behavioral $\quad$ sciences, 182, https://doi.org/10.1016/j.sbspro.2015.04.729

Obiakor, T., \& Adeniran, A. P. (2020). Covid-19: Impending Situation Threatens to Deepen Nigeria's Education Crisis.

Pangondian, R. A., Santosa, P. I., \& Nugroho, E. (2019). Faktor-Faktor Yang Mempengaruhi Kesuksesan Pembelajaran Daring Dalam Revolusi Industri 4.0. In Seminar Nasional Teknologi Komputer \& Sains (SAINTEKS) (Vol. 1, No. 1).

Purwaningsih, D., \& Pujianto. (2009). Blended Cooperative E-learning (BCEL) sebagai sarana pendidikan penunjang learning community. Paper. Disampaikan dalam Seminar Nasional UNY dengan tema "Peranan ICT (Information and Communication Technology) dalam Pembelajaran” pada tanggal 25 Juli 2009 di Ruang Sidang Utama Rektorat UNY.

Purwanto, A., Pramono, R., Asbari, M., Hyun, C. C., Wijayanti, L. M., \& Putri, R. S. (2020). Studi Eksploratif Dampak Pandemi COVID-19 Terhadap Proses Pembelajaran Online di Sekolah Dasar. EduPsyCouns: Journal of Education, Psychology and Counseling, 2(1), 1-12.

Richy, R. C., Klein, J. D., \& Tracey, M. W. (2011). The instructional design knowledge base.

Rohman, M. F. (2017). Learning Management System Schoology. Bojonegoro: Pustaka Intermedia.

Rusman, M. P., \& Cepi, R. (2012). Belajar dan Pembelajaran Berbasis Komputer. Bandung: Alfabeta.

Rusman. (2011). Model-model pembelajaran: Mengembangkan profesionalisme guru. Rajawali Pers/PT Raja Grafindo Persada.

Semler, S. (2005). Use blended learning to increase learner engagement and reduce training cost. On-line) dalam http://www. learningsim. com/content/lsnews/blended_learning1. html. Diunduh, 11 .

Semradova, I., \& Hubackova, S. (2016). Teacher responsibility in distance education. Procedia-Social and Behavioral Sciences, 217, 544-550. https://doi.org/10.1016/j.sbspro.2016.02.042

Sicat, A. S. (2015). Enhancing college students' proficiency in business writing via schoology. International Journal of Education and Research, 3(1), 159-178.

Simbolon, N. (2014). Faktor-faktor yang mempengaruhi minat belajar peserta didik. Elementary School Journal Pgsd Fip Unimed, 1(2).

Darma, I. K., Karma, I. G. M. ., \& Santiana, I. M. A. . (2020). Validation of blended learning model of applied mathematics through schoological networks for learning in new normal era in vocational education. International Research Journal of Engineering, IT \& Scientific Research, 6(6), 50-60. https://doi.org/10.21744/irjeis.v6n6.1027 
Smaldino, S. E., \& Lowther, D. L. dan Russel, JD (2012). Instructional technology and media for learning: Teknologi pembelajaran dan media untuk belajar.

Soekendro, H. (2020). Blended Learning Bisa Jadi Inovasi Pendidikan Saat Pandemi Corona.

Stockwell, B. R., Stockwell, M. S., Cennamo, M., \& Jiang, E. (2015). Blended learning improves science education. Cell, 162(5), 933-936. https://doi.org/10.1016/j.cell.2015.08.009

Sudiarta, I. G. P., \& Sadra, I. W. (2016). Pengaruh model blended learning berbantuan video animasi terhadap kemampuan pemecahan masalah dan pemahaman konsep siswa. Jurnal Pendidikan dan pengajaran, 49(2), 4858.

Sudira, P. (2018). Metodologi pembelajaran vokasional abad XXI.

Suparno, A. S. (2000). Membangun kompetensi belajar. Direktorat Jenderal Pendidikan Tinggi.

Sutopo, H., D. (2012). Teknologi Informasi dan Komunikasi dalam Pendidikan. Yogyakarta: Graha Ilmu

Trianto, A.I.B. (2015). Mendesain Model Pembelajaran Inovatif, Progresif, dan Kontekstual. Jakarta: Prenadamedia Grup.

Uden, L., \& Beaumont, C. (2006). Why problem-based learning. In Technology and problem-based learning (pp. 4464). IGI Global.

Watson, J., \& Murin, A. (2014). A history of K-12 online and blended instruction in the United States. In Handbook of research on K-12 online and blended learning (pp. 1-23).

Wong, K. T., Hamzah, M. S. G., Goh, P. S. C., \& Yeop, M. A. B. (2016). Blended e-learning acceptance as smart pedagogical tools: An initial study in Malaysia. Turkish Online Journal of Educational TechnologyTOJET, 15(4), 25-31.

Yagci, M. (2016). Blended Learning Experience in a Programming Language Course and the Effect of the Thinking Styles of the Students on Success and Motivation. Turkish Online Journal of Educational TechnologyTOJET, 15(4), 32-45.

Yengin, I., Karahoca, A., Karahoca, D., \& Uzunboylu, H. (2011). Deciding which technology is the best for distance education: Issues in media/technology comparisons studies. Procedia Computer Science, 3, 1388-1395. https://doi.org/10.1016/j.procs.2011.01.020

Zayed, E. M. (2011). A note on the modified simple equation method applied to Sharma-Tasso-Olver equation. Applied Mathematics and Computation, 218(7), 3962-3964. https://doi.org/10.1016/j.amc.2011.09.025

Zhang, D., Zhao, J. L., Zhou, L., \& Jay, F. N. (2004). J.(2004). Can e-learning replace classroom learning. Commun. ACM, 47(5), 75-79. 